\title{
A CRITIQUE ON LEASE VERSUS BUY ANALYSIS AND GOVERNMENT TAX REVENUE
}

\author{
Dr. Guan Jun Wang \\ Associate Professor of Finance \\ College of Business Administration \\ Savannah State University, USA \\ E-mail:wangg@savannahstate.edu
}

\begin{abstract}
Motivation for leasing is often believed to be the tax rate difference between the lessee and the lessor, allowing both to save on taxes at the government's expense. These short notes challenge this conventional wisdom and demonstrate not only the tax rate difference but also other various leasing parameters that can have an impact on government tax revenue both analytically and numerically. This paper adds additional theoretical groundworks to the literature to support the claim that the positivesum games do exist among the lessee, the lessor, and the government.
\end{abstract}

Keywords: Lease, Purchase, Government Tax Revenue, Tax Credit.

JEL Classification Codes: C6, G3.

\section{INTRODUCTION}

When a firm wishes to obtain the use of an asset, it can either purchase it or lease it. A lease is a contractual agreement under which the owner of an asset (the lessor) temporarily transfers the right to use an asset to another party (the lessee). The lessor typically makes the lease for a specified time in return for periodic leasing payments from the lessee.

Leasing not only facilitates the acquisition of equipment, plant, and machinery without the necessary capital outlay, but also provides the other advantages to lessees as mentioned in mainstream managerial finance textbooks which include high operating flexibility, risk reduction of technological obsolete, and uncertain demand, and also the tax advantages: A firm that leases equipment or real estate, for example, will be able to deduct its lease payments from its taxable income immediately rather than deducting the cost of purchasing as depreciation over time.

Lessors have many advantages to leasing their assets as well. Compared to lessees, they are often able to obtain favorable financing terms and acquire equipment at a lower cost due to their financial status advantage (lessors are typically big finance companies) and various economies of scale. Lessors are also better positioned to take advantage of depreciation allowances and other tax credits.

Among these benefits, tax considerations are often believed to be the key determinant that firms choose to lease over buying. When a firm purchases equipment, it obtains the tax benefit of depreciating that equipment's cost. Since the depreciation allowance is more attractive to firms in a higher tax bracket, the common wisdom is that the firm that needs to use the equipment lets a firm who is usually in a higher tax bracket purchase the equipment and passes on the benefit of depreciation advantage to the lessee in the form of reduced lease payments. The lessee can also arrange to adjust lease rentals in such a way that it reduces its tax liability and thus helps the firm in tax planning. But what about the government? 
Many leading managerial finance textbooks claim that because both the lessor and lessee gain tax benefit from the transfer of depreciation from an asset's user to the lessor who buys it, the government is a net loser. For example, Ross, Westerfield, and Jordan (2019) contend that "The loser will be the IRS". Brealey, Myers, and Allen (2020) also state that "the government suffers net loss in the present value of its tax receipts as a result of the lease". This conventional wisdom is also found in Brigham and Daves (2019), Brigham and Ehrhardt (2017), and Emery, Finnerty, and Stowe (2018). The perspective of the lessee and lessor as paying lower combined taxes (which is equivalent to the government's collecting less tax revenue) is not limited to just textbooks but also claimed in early literature. For example, Myers, Dill, and Bautista (1976) claim that "saving taxes seems to be the only motive that is obvious and substantial, and Smith and Wakeman (1985) state "leasing can reduce total tax bill".

However, there are a few exceptions. Recently, Berk and DeMarzo (2020), show by a numerical example only without exploring their ideas analytically that leasing can generate tax advantage to the government as well when the lessee has a higher tax rate and the lease payments are sufficiently high to cover the depreciation and interest deductions. Musumeci and O'Brien (2019) emphasize the difference in lessee and lessor's borrowing rates to challenge the "conventional wisdom". They argue that a difference in lessee and lessor's borrowing rates may be a more important source of a lease's overall benefit than a difference in the tax rates but failed to provide enough theoretical ground to support their claim.

This paper is not only intended to close this theory-practice gap by providing more theoretical grounds but also examines other factors like depreciation methods and lease payment schedules on the impact of leasing on government tax revenue both analytically and numerically. Differ from Musumeci and O'Brien (2019) and earlier research methodologies, this paper evaluates the government's overall net tax revenue effect as a government capital budgeting problem and it is measured as the present value of the net tax revenue in each period and the discounted cash flow analysis is configured based on after-tax cash flows discounted with after-tax discount rates according to Lonergan (2009). The theoretical framework this paper presents also enables one to examine the effect of not only tax rates difference but also other leasing parameters on the government's net tax revenue in a more straightforward manner.

\section{REVIEW OF LEASE VERSUS PURCHASE ANALYSIS}

The modern agreed-upon conceptual textbook framework of lease vs. purchase analysis is formulated on the notion that a lease contract is equivalent to a loan agreement. Thus, "lease versus borrow-andbuy" is a more accurate description of the modern textbook framework than the simple term of "lease versus purchase". Since the lease or purchase decision doesn't affect the asset user's operating cash flows, they often are excluded in a lease versus purchase analysis. The net advantage to lease (NAL) ${ }^{1}$ is the difference between the foregone initial investment cash outlay and the present value of the lease's net cash outflows (LNCOs), where each period's LNCO is the sum of the following three components: (1) the depreciation tax credit foregone as a result of the foregone purchase, (2) the after-tax lease payment (lease payments are tax-deductible); and (3) the interest tax credit foregone on the imagined

\footnotetext{
${ }^{1}$ The NAL analysis within the textbook framework was evolved from the early insights of Myers, S. C., Dill, D. A., \& Bautista, A. J. (1976), Lewellen, W. G., Long, M. S., \& McConnell, J. J. (1976) and Levy, H., \& Sarnat, M. (1979).
} 
loan if the purchase had been made? If the present value of $\mathrm{NAL}^{2}$ in each period is positive, the asset user would benefit from leasing thus would choose leasing rather than borrowing-to-buy.

Whether the lessor would benefit from the lease agreement is a capital budgeting valuation problem. The net present value (NPV) of the project which is the proposed lease is the difference between the present value of the lessor's net cash inflows and the initial investment outlay (purchasing price). The lessor's net cash inflows in each period are the following three components: (1) the after-tax lease revenue; (2) the depreciation tax credit; (3) the interest tax credit on the loan. If the net present value $(\mathrm{NPV})^{3}$ is positive, lessor benefits from the leasing. The earlier framework, such as Lewellen, Long, and McConnell (1976), uses the before the cost of debt as the discount rate for the present value calculation for the reason that such framework explicitly includes the interest tax credits as a component of each period's cashflows. The modern standard textbook approaches use the after-tax cost of debt as the discount rate for the reason that it ignores the interest tax credits. Though Long (1980) and Musumeci and O'Brien (2019) state the two approaches are equivalent which this paper doesn't agree with, they failed to explore their ideas analytically. Lonergan (2009) uses various examples to show the two approaches are not equivalent and argues that discounted cash flow analysis should be configured based on after-tax cash flows discounted with after-tax discount rates. This paper adopts Lonergan (2009)'s approach that the preferred (and technically correct) method to discount cash flows is to express cash flows forecasts on an after-tax basis and to discount those cash flows using an aftertax discount rate and treats government's net tax effect as a government's capital budgeting problem whose cash flows are affected by both lessor and lessee's interest rate, so in below discussion, the interest tax credits are explicitly included as a component of each period's cash flows and after-tax rates are used as the discount rates as Lonergan (2009) suggests.

\section{LEASING IMPACT ON GOVERNMENT TAX REVENUE}

The standard textbook analysis of a user's lease vs. purchase decision emphasizes the tax-deductible amount: lease payment to the lessee and depreciation to the lessor (purchaser), but overlooks the other leasing parameters.

Let $D_{n}$ denote depreciation in year $\mathrm{n}, L_{n}$ lease payment in year $\mathrm{n}$, and $I_{p n}$ purchaser (buyer)'s interest payment in year $\mathrm{n}$ (if the buyer uses $100 \%$ equity financing for the purchase, $I_{p n}=0$ ), $I_{\mathrm{ln}}$ interest payment in year $\mathrm{n}$ incurred to the lessee if the lessee had chosen to borrow and buy, $T_{p}$ purchaser (lessor)'s tax rate, $T_{l}$ lessee's tax rate. Then the tax difference between leasing and purchasing in year $\mathrm{n}$ to the lessee is

$-\left(L_{n}-D_{n}-I_{\mathrm{ln}}\right) T_{l}$

The net (additional) tax the lessor pays in year $\mathrm{n}$ (to the lessor leasing payment is the revenue) as a result of purchasing then leasing out is

$\left(L_{n}-D_{n}-I_{p n}\right) T_{p}$

\footnotetext{
${ }^{2}$ Differ from Musumeci and O'Brien (2019) and earlier research's methodologies, the discounted cash flow analysis this paper adopts is configured based on after-tax cash flows discounted with after-tax discount rates according to Lonergan (2009)

${ }^{3}$ The discounted cash flow analysis is configured based on after-tax cash flows discounted with after-tax discount rates according to Lonergan (2009)
} 
The total effect on the government's net tax revenue in year $\mathrm{n}\left(N T R_{n}\right)$ as a result of the leasing arrangement is the sum of the above two, that is,

$$
N T R_{n}=\left(L_{n}-D_{n}-I_{p n}\right) T_{p}-\left(L_{n}-D_{n}-I_{\mathrm{ln}}\right) T_{l}
$$

By stating $N T R_{n}$ in this way, it is clear that whether the government is a loser or gainer depends on both parties' tax rates and borrowing rates, depreciation methods, and leasing contract stating the payment schedule (amount and timing) and the overall government's net tax effect can be evaluated using the present value of each period's net tax revenue from the leasing. Following Park (2012), this paper uses the risk-free rate as the discount rate to evaluate government projects. If both parties have the same tax rate and interest rate and use debt to finance the purchase, the government's net tax revenue in year $\mathrm{n}\left(N T R_{n}\right)$ is zero, that is, leasing does not affect government tax revenue.

To illustrate the point, let's use the same numerical example seen in Ross, Westerfield, Jaffe, and Jordan (2019). In that scenario, the user wants equipment that costs $\$ 10,000$ and that may be depreciated straight-line for 5 years $\left(D_{n}=\$ 2,000\right)$ with a salvage value of zero. A leasing company offers to lease the equipment to the user for an annual lease payment of \$2393 per year. Lessor and lessee are assumed to have the same interest rates of $6.329 \%$ which implies annual interest payment $I_{p n}=\$ 632.9$, but their tax rates vary lessee $T_{l}=0 \%$ and lessor $T_{p}=21 \%$. Under these assumptions, because of the lessee's zero tax rate, it is easy to calculate the lessee's NAL $=\$ 9.40$ which is the difference between the foregone initial outlay and the present value of five- years annuity of leasing payment discounted at $6.329 \%$. Since the lessor has an effective tax rate of $21 \%$, its after-tax lease revenue is $2393(1-21 \%)=1890.47$, its depreciation tax credit is $2000 x 21 \%=420$ and interest tax credit 132.91(=10000x6.329\%x21\%). Therefore lessor's annual after-tax cash inflows without including interest tax credit are $1890.47+420=2310.47$. The present value of this five-year annuity of 2310.47 discounted at the lessor's after-tax cost of debt of $5 \%(=6.329 \%(1-21 \%))$ is $10,003.13$, therefore lessor's NPV $=\$ 3.13$ which is the answer shown in the textbook.

Lonergan (2009) points out the conceptual flaws in traditional discount cash flows analysis. If Lonergan's (2009) approach is used by including the interest tax credit of 132.91 in the cash flows, the lessor's NPV increases by 575.39 which is the present value of the interest tax credits. Both positive numbers of lessee's NAL and lessor's NPV indicate that both lessee and lessor benefit from the leasing arrangement. The annual government's net tax revenue $N T R_{n}=(2,393-2,000-632.9) \times 21 \%=-\$ 50.3$. The negative number $N T R_{n}$ supports the conventional wisdom that the government is a loser in such leasing arrangements. However, that result could change if the assumptions on tax rates, borrowing rates, depreciation methods, lease schedule, etc. are varied. As mentioned earlier, if the lessor and lessee have the same tax rates and interest rates, $N T R_{n}$ is zero which means leasing does not affect government tax revenue. Below we will discuss other scenarios.

\section{Scenario 1: Higher Tax Rate on Lessee}

To take the advantages of the leasing which include high operating flexibility, risk reduction of technological obsolete and uncertainty of the demand, though it is rare, firms in high tax brackets sometimes choose to lease rather than buy to forego depreciation tax benefit. If the lessee is a big 
manufacturing company whose tax bracket is higher ${ }^{4}$ than lessor's $(21 \%)$, other things being equal in the previous example, it is easy to see $N T R_{n}=\left(L_{n}-D_{n}-I_{p n}\right) T_{p}-\left(L_{n}-D_{n}-I_{\mathrm{ln}}\right) T_{l}>0$

This means the government will benefit from the leasing arrangement, thus not a loser but a gainer. Of course in this scenario, the lessee pays more taxes than that if purchasing had been chosen.

\section{Scenario 2: Unequal Borrowing Rates, Tax Rates Under Normal Circumstances}

Under Normal Circumstances, leasing companies are typically large finance companies (many banks have leasing arms) while the lessees are typically small industrial companies, in such instance, the following is usually true: $T_{p}>T_{l}$ and $I_{p n}<I_{\ln }$ (larger companies usually pay lower borrowing rates). The net effect on government tax revenue $N T R_{n}\left(=\left(L_{n}-D_{n}-I_{n}\right) T_{p}-\left(L_{n}-D_{n}-I_{\mathrm{ln}}\right) T_{l}\right)$ could be either positive or negative.

\section{Scenario 3: Unequal Tax Rates, Borrowing Rates, Accelerated Depreciation}

Under accelerated depreciation assumption, the government's net tax revenue in year n $\left(N T R_{n}\right)$ can vary depending on the leasing payment schedule, depreciation method, lessor and lessee's tax rates, and borrowing rates and they can be either positive or negative, and the present value of all $N T R_{n}$ also depends on the risk-free rate (the discount rate). The government's net tax revenue effect can be treated as a government capital budget problem and a risk-free rate should be used as the discount rate as suggested by Park (2012).

Assume depreciation follows a five-year modified accelerated cost recovery system (MACRS) and a risk-free rate of $3 \%$. Tables 2-5 show the results under various assumptions on leasing parameters. The government's net tax revenues are shown in the last column of these Tables (Table 1 presents a simple straight-line depreciation example).

Table 1. The Government's Net Tax Revenue(Straight-line depreciation)

\begin{tabular}{|c|c|c|c|c|c|}
\hline Year & $\begin{array}{c}\text { Lease } \\
\text { Payment } \\
L_{n}\end{array}$ & $\begin{array}{c}\text { Depreciation } \\
D_{n}\end{array}$ & $\begin{array}{c}\text { Lessor's Interest } \\
\text { payment } \\
I_{p n}\end{array}$ & $\begin{array}{c}\text { Lessee's foregone } \\
\text { Interest deductible } \\
I_{\ln }\end{array}$ & $\begin{array}{c}\text { Government's Net } \\
\text { Tax Revenue } \\
N T R_{n}\end{array}$ \\
\hline 1 & 2393 & 2000 & 632.9 & 632.9 & -50.38 \\
\hline 2 & 2393 & 2000 & 632.9 & 632.9 & -50.38 \\
\hline 3 & 2393 & 2000 & 632.9 & 632.9 & -50.38 \\
\hline 4 & 2393 & 2000 & 632.9 & 632.9 & -50.38 \\
\hline 5 & 2393 & 2000 & 632.9 & 632.9 & -50.38 \\
\hline
\end{tabular}

Assumptions: \$2393 annual leasing payment, 5-year straight-line depreciation, same borrowing rates of $6.329 \%$ for lessor and lessee, no tax imposed on the lessee, lessor's tax rate of $21 \%$, risk-free rate of $3 \%$. The lessee's $N A L=9.40^{5}$ and the Lessor's $N P V=578.58^{6}$, and the present value of government's net tax revenue $\operatorname{NTR}_{n}(n=1,2,3,4$ and 5) (discounted at risk free rate of 3\%) is -230.72. Conventional wisdom holds!

\footnotetext{
${ }^{4}$ This assumption is consistent with the Eades, K. M., and Marton, E. C. (2002) survey findings for large lessors and lessees. ${ }^{5}$ Difference between the foregone initial outlay of 10,000 and PV of the five-year annuity of 2393 discounted at $6.329 \%$

${ }^{6}$ Difference between the present value of the sum of after-tax lease payment and depreciation and interest tax credits in each period discounted at $5 \%(=6.329 \%(1-21 \%))$ and the initial outlay of 10,000 .
} 
Table 2. The Government's Net Tax Revenue (5-year MACRS depreciation)

\begin{tabular}{|c|c|c|c|c|c|}
\hline Year & $\begin{array}{c}\text { Lease } \\
\text { Payment } \\
L_{n}\end{array}$ & $\begin{array}{c}\text { Depreciation } \\
D_{n}\end{array}$ & $\begin{array}{c}\text { Lessor's Interest } \\
\text { payment } \\
I_{p n}\end{array}$ & $\begin{array}{c}\text { Lessee's } \\
\text { foregone Interest } \\
\text { deductible } \\
I_{\text {ln }}\end{array}$ & $\begin{array}{c}\text { Government's Net Tax } \\
\text { Revenue } \\
N T R_{n}\end{array}$ \\
\hline 1 & 2393 & 2000 & 632.9 & 632.9 & -50.38 \\
\hline 2 & 2393 & 3200 & 632.9 & 632.9 & -302.38 \\
\hline 3 & 2393 & 1920 & 632.9 & 632.9 & -33.58 \\
\hline 4 & 2393 & 1152 & 632.9 & 632.9 & 127.7 \\
\hline 5 & 2393 & 1152 & 632.9 & 632.9 & 127.7 \\
\hline 6 & & 576 & & & -120.96 \\
\hline
\end{tabular}

Assumptions: \$2393 annual leasing payment,5-year MACRS depreciation, same borrowing rates of $6.329 \%$ for lessor and lessee, no tax imposed on the lessee, lessor's tax rate of $21 \%$, and the risk-free rate of 3\%. The lessee's $N A L=9.40$ and the Lessor's NPV=596.86, and the present value of the government's net tax revenue $(n=1,2,3,4$, and 5) is -242.35 . Conventional wisdom holds!

Table 3. The Government's Net Tax Revenue(5-year MACRS depreciation, different borrowing rates)

\begin{tabular}{|c|c|c|c|c|c|}
\hline Year & $\begin{array}{c}\text { Lease } \\
\text { Payment } \\
L_{n}\end{array}$ & $\begin{array}{c}\text { Depreciation } \\
D_{n}\end{array}$ & $\begin{array}{c}\text { Interest payment } \\
I_{p n}\end{array}$ & $\begin{array}{c}\text { Lessee's } \\
\text { foregone Interest } \\
\text { deductible } \\
I_{\text {ln }}\end{array}$ & $\begin{array}{c}\text { Government's Net } \\
\text { Tax Revenue } \\
N T R_{n}\end{array}$ \\
\hline 1 & 2393 & 2000 & 350 & 632.9 & 9.03 \\
\hline 2 & 2393 & 3200 & 350 & 632.9 & -242.97 \\
\hline 3 & 2393 & 1920 & 350 & 632.9 & 25.83 \\
\hline 4 & 2393 & 1152 & 350 & 632.9 & 187.11 \\
\hline 5 & 2393 & 1152 & 350 & 632.9 & 187.11 \\
\hline 6 & & 576 & & & -120.96 \\
\hline
\end{tabular}

Assumptions: \$2393 annual leasing payment, 5-year MACRS depreciation, borrowing rate of 6.329\% for the lessee and 3.5\% for the lessee, no tax imposed on the lessee, lessor's tax rate of 21\%, risk-free rate of 3\%.Lessee's $N A L=9.40$, lessor's $N P V=1002.32$, and the present value of five-year government net tax revenue $\operatorname{NTR}_{n}(n=1,2,3,4$, and 5$)$ is 29.73.A positive-sum game!

Table 4. The Government's Net Tax Revenue (5-year MACRS depreciation, different borrowing rates, positive tax rate on lessee)

\begin{tabular}{|c|c|c|c|c|c|}
\hline Year & $\begin{array}{c}\text { Lease } \\
\text { Payment } \\
L_{n}\end{array}$ & $\begin{array}{c}\text { Depreciation } \\
D_{n}\end{array}$ & $\begin{array}{c}\text { Interest payment } \\
I_{p n}\end{array}$ & $\begin{array}{c}\text { Lessee's } \\
\text { foregone Interest } \\
\text { deductible } \\
I_{\ln }\end{array}$ & $\begin{array}{c}\text { Government's Net } \\
\text { Tax Revenue } \\
N T R_{n}\end{array}$ \\
\hline 1 & 2393 & 2000 & 350 & 832.9 & 53.02 \\
\hline 2 & 2393 & 3200 & 350 & 832.9 & -78.98 \\
\hline
\end{tabular}




\begin{tabular}{|c|c|c|c|c|c|}
\hline 3 & 2393 & 1920 & 350 & 832.9 & 61.82 \\
\hline 4 & 2393 & 1152 & 350 & 832.9 & 146.3 \\
\hline 5 & 2393 & 1152 & 350 & 832.9 & 146.3 \\
\hline 6 & & 576 & & & -63.36 \\
\hline
\end{tabular}

Assumptions: \$2393 annual leasing payment,5-year MACRS depreciation, borrowing rates for lessor3.5\%, 8.329\% for lessee, 10\% tax rate for lessee, lessor's tax rate of 21\%, risk free rate of $3 \%$, and lessee's $N A L=127.05$ Lessor's $N P V=1002.32$, and the present value of five year government net tax revenue $\operatorname{NTR}_{n}(n=1,2,3,4,5)$ is 236.73 . A positive-sum game!

Table 5. The Government's Net Tax Revenue (5-year MACRS depreciation, high lease payment)

\begin{tabular}{|c|c|c|c|c|c|}
\hline Year & $\begin{array}{c}\text { Lease } \\
\text { Payment } \\
L_{n}\end{array}$ & $\begin{array}{c}\text { Depreciation } \\
D_{n}\end{array}$ & $\begin{array}{c}\text { Interest payment } \\
I_{p n}\end{array}$ & $\begin{array}{c}\text { Lessee's } \\
\text { foregone Interest } \\
\text { deductible } \\
I_{\text {ln }}\end{array}$ & $\begin{array}{c}\text { Government's Net } \\
\text { Tax Revenue } \\
\text { NTR }\end{array}$ \\
\hline 1 & 2600 & 2000 & 632.9 & 1032.9 & 14.74 \\
\hline 2 & 2600 & 3200 & 632.9 & 1032.9 & -177.26 \\
\hline 3 & 2600 & 1920 & 632.9 & 1032.9 & 27.54 \\
\hline 4 & 2600 & 1152 & 632.9 & 1032.9 & 150.42 \\
\hline 5 & 2600 & 1152 & 632.9 & 1032.9 & 150.42 \\
\hline 6 & & 576 & & & -92.16 \\
\hline
\end{tabular}

Assumptions: $\$ 2600$ annual leasing payment,5-year MACRS depreciation, borrowing rates for lessor $6.329 \%, 10.329 \%$ for lessee, 5\% tax rate for lessee, lessor's tax rate of $21 \%$, risk free rate of $3 \%$, and lessee's $N A L=6.68$ Lessor's $N P V=1304.86$, and the present value of five year government net tax revenue $\operatorname{NTR}_{n}(n=1,2,3,4,5)$ is 58.63. A positive-sum game!

\section{CONCLUSION}

This paper discusses the leasing impact on government tax revenue both analytically and numerically. Different from earlier research methodologies, it first develops a theoretical framework and treats leasing impact on the government's net tax revenue as a capital budgeting problem. The theoretical framework this paper presents also enables one to examine the effect of not only tax rates difference but also other leasing parameters on the government's net tax revenue in a more straightforward manner. Another notable difference is that this paper conducts discounted cash flow analysis based on after-tax cash flows discounted with after-tax discount rates according to Lonergan (2009). Knowing sources of the impact and how they impact has important policy implications, specifically, because the positive-sum games do exist among the lessor, lessee, and government, efforts to restrict what qualifies as a lease can be counterproductive as far as government revenues are concerned. This paper adds additional theoretical groundworks to the literature and provides insights that are not well known within the textbook framework and should be useful to both instructors and practitioners.

\section{REFERENCES}

Berk, J., \& DeMarzo, P. (2020). Corporate Finance, $5^{\text {th }}$ Edition, Pearson. 
Brealey, R. A., Myers, S. C., \& Allen, F. (2020). Principles of Corporate Finance, $13^{\text {th }}$ Edition, McGraw-Hill Irwin.

Brighham, E. F., \& Daves, P. R. (2019). Intermediate Financial Management, $13^{\text {th }}$ Edition, Cengage Learning.

Brigham, E. F., \& Ehrhardt, M. C. (2017). Financial Management: Theory and Practice, $15^{\text {th }}$ Edition, Cengage Learning.

Eades, K. M., \& Marton, E. C. (2002). Incentives for Leasing: Evidence from the Largest U.S. Lessees and Lessors, University of Virginia Working Paper.

Emery, D. R., Finnerty, J. D., \& Stowe, J. D. (2018). Corporate Financial Management, $5^{\text {th }}$ Edition, Wohl Publishing.

Lewellen, W. G., Long, M. S., \& McConnell, J. J. (1976). Asset Leasing in Competitive Capital Markets, Journal of Finance, 53(1), 131-162.

Levy, H., \& Sarnat, M. (1979). Leasing, Borrowing, and Financial Risk, Financial Management, 8(4). 47-54.

Lonergan, W. (2009). Pre and Post Tax Discount Rates and Cash Flows-A Technical Notes, the Journal of Applied Research in Accounting and Finance, 4(1), 41-45.

Long, M. S. (1980). Using a Before or After Tax Discount Rate in the Lease-Buy Decision, the Engineering Economist, 26(4), 263-274.

Musumeci, J., \& O’Brien, T. (2019). Lease vs Buy: Clarifying the Impact of tax and Borrowing Rates, Managerial Finance, 45(5), 686-696.

Myers, S. C., Dill, D. A., \& Bautista, A. J. (1976). Valuation of Financial Lease Contracts, Journal of Finance, 31(3), 799-819.

Park, S. (2012). Optimal Discount Rate for Government Projects, International Scholarly Research Network, ISRN Economics.

Ross, S. A., Westerfield, R. W., \& Jordan, B. D. (2019). Corporate Finance, $13^{\text {th }}$ Edition, McGrawHill Irwin.

Smith, C. W., \& Wakeman, M. (1985). Determinants of Corporate Leasing Policy, Journal of Finance, 40(3), 895-908.

\section{Copyrights}

Copyright for this article is retained by the author(s), with first publication rights granted to the journal. This is an open-access article distributed under the terms and conditions of the Creative Commons Attribution license (http://creativecommons.org/licenses/by/4.0/) 